\title{
Study of the Production of "Dadawa" from Seeds of Amblygonocarpus andongensis in Adamawa, Cameroon
}

\author{
BOURSI Jérémie $^{1 *}$, ABEGA Juste Philantrope $^{2}$, HOUJAYFA MOHAMAD OUSMAN ${ }^{3}$, DAZECK \\ DOUMBA Fanny Rosette ${ }^{4}$, AMINATOU Hamida $^{5}$, ADJOUDJI OUSMAN $^{6}$
}

1-6 Institute of Agriculture Research and Development (IRAD), Wakwa Regional Research Center, P.O. Box 65, Ngaoundere, Cameroon

${ }^{1}$ Department of Biological Sciences, Faculty of Science, The University of Ngaoundere, P.O. Box 454, Ngaoundere, Cameroon

${ }^{2}$ Laboratory of Plant Physiology, Department of Biological Sciences, Higher Teachers' Training College, University of Yaounde1 P.O. Box 47, Yaounde, Cameroon

${ }^{3-6}$ National Advanced School of Agro-Industrial Sciences, P.O. Box 455, Ngaoundere, Cameroon

\begin{abstract}
The present study aims to analyze the production system of "Dadawa" based on the seeds of Amblygonocarpus andongensis. Surveys were carried out among processors in the Nyambaka district in the Adamawa region from November 2020 to December 2020. The traditional "Dadawa" manufacturing process consumes more effort and time. It does not vary by ethnicity, age, and level of education. It includes several operations: The first phase being doble cooking which lasts for about 12 hours and the second whose duration is about 30 minutes aerobic fermentation takes place for 72hours, the leaves of Annona senegalensis are used during this operation, the fermented product is dried in the sun. The product obtained is similar to that obtained from the seeds of Parkia biglobosa but it is more appreciated by the population because of its more pronounced taste.
\end{abstract}

Key Words: Amblygonocarpus andongensis, Dadawa, Production system, Nyambaka.

\section{INTRODUCTION}

Amblygonocarpus andongensis (Mimosaceae) is widely spread in tropical Africa, mostly in the Savannah areas (Nwinyi et al., 2006). Amblygonocarpus is a genus of flowering plants in the legume family, Fabaceae belonging to sub family Mimosoideae. It is usually 30-40 feet high, but reaching 60 feet and 5 feet girth in moist areas (Nwiyi et al., 2006, Ugwah et al., 2014). The leaves are mostly at the ends of the erect twig and entirely glabrous with leaflets pale-blue-green. The flowers are white or yellowish and sweetly scented. The fruits are dark brown, 4-5 inches long by about 1 inch across, hanging on thick stalks 2-3 inches long (Keay et al., 1964). Ecosystems of the northern region of Cameroon has a large variety of non-timber forest products (Mapongmetsem $e t$ al., 2008). Amblygonocarpus andongensis is one of the species that provides the non-wood forest products, its seeds thus contribute to the family self-consumption of the populations of the Nyambaka zone (Mapongmetsem et al., 2008). Commonly called "yaké" in Fulfulde in Cameroon. These seeds are traditionaly used as spices called "dadawa" in the preparation of various meals in Cameroon (Mapongmetsem et al., 2012). This spice acts as a substitute of maggi cube. This non-timber forest product plays a very important role in the daily diet of the population through its nutritional quality out, and is also a source of income for the populations (Mapongmetsem and Laissou, 2010). The scarsity of scientific, technical information and commercial prospects of this plant are the greatest constaint to its valorization product (Moupela et al., 2011). The objective of this work is to analyze the "dadawa" production system based on the seeds of Amblygonocarpus andongensis in order to add value to this non-wood forest product and to enhance it technologically. 


\section{MATERIALS AND METHODS}

\subsection{PLANT MATERIAL:}

Study material consists of Amblygonocarpus andongensis dry seeds
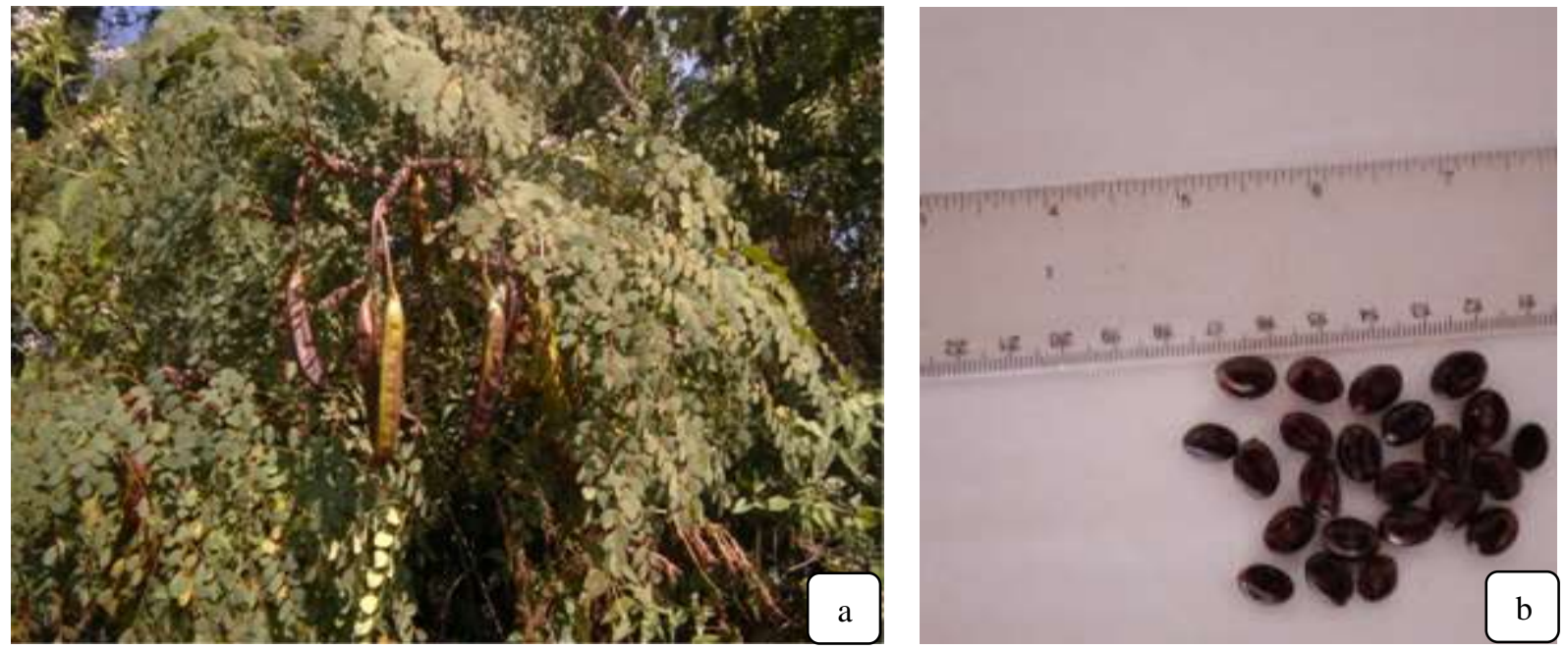

Figure 1: Fruits on the stem (a) and seeds of Amblygonocarpus andongensis

\subsection{MAP NEEDED}

The study was conducted in Nyambaka in Guinean Savannah Highlands (GSH) of Adamawa in Cameroon. It is located between $6^{\circ} 89^{\prime}$ North; $14^{\circ} 09^{\prime}$ East, and is at $1280 \mathrm{~m}$ above sea level. The climate of the area is of the Sudano-Guinean type, characterized by two seasons: a dry season that lasts for about five months and a rainy season that lasts about seven months. The soil of the region is constituated in majority of red ferralitic structure developped on old basalt (Yonkeu, 1983). The area is covered with shrub and woody savannah dominated by Daniellia oliveri and Lophira lanceolata (Letouzey, 1968).

\subsection{METHOD OF SURVEY}

100 women involved in the transformation of this product were randomly chosen in Nyambaka locality. Survey was conducted from November 2020 to December 2020, using a semi-structured questionnaire as the survey instrument. The questioner contained closed questions (the respondent reacts with yes or no), open questions (the respondent responded deliberately according to her point of view) and multiple-choice questions (the respondent chooses one or more answers from the list of proposed answers). The main topics covered concerned the traditional technology of transforming seeds into spice, and the materials used. The socio-demographic characteristics of the respondents were also recorded.

2.4 DATA ANALYSIS: Data are analyses by using Excel 2010 software.

\section{RESULTS AND DISCUSSION}

\subsection{SOCIO-DEMOGRAPHIC CHARACTERISTICS OF THE SURVEYS}

The socio-demographic characteristics (Mboum, Peulh and Gbaya.). The Gbaya constituted the majority (43\%) (Table 1). On the other hand, the Peulh were less represented with a rate of 28\%, the work carried out by Lamy et al. (2018) on Syzygium guineense var. macrocarpum shows that the Mboum (40.37\%) know this species better.

Table 1: Ethnic groupes of interviewers.

\begin{tabular}{ll}
\hline Ethnic & Percentage \\
\hline Mboum & 29 \\
Peulh & 28 \\
Gbaya & 43 \\
\hline
\end{tabular}


People aged between 25 and 35 are the most represented (36\%). They were followed by those between 35 and 45 years old (21\%). Individuals between 65 and 75 years of age (6\%) were relatively less represented (Figure 1). These results disagree with those of N'zebo et al. (2018) in Côte d'Ivoire on Tetrapleura tetraptera. According to these authors, people aged over 60 are the most represented $(89.19 \%)$. This could be explained by the fact that in this area, the transmission of endogenous knowledge is ensured by the elderly. Producing this spice takes a lot of effort that older people cannot easily provide.

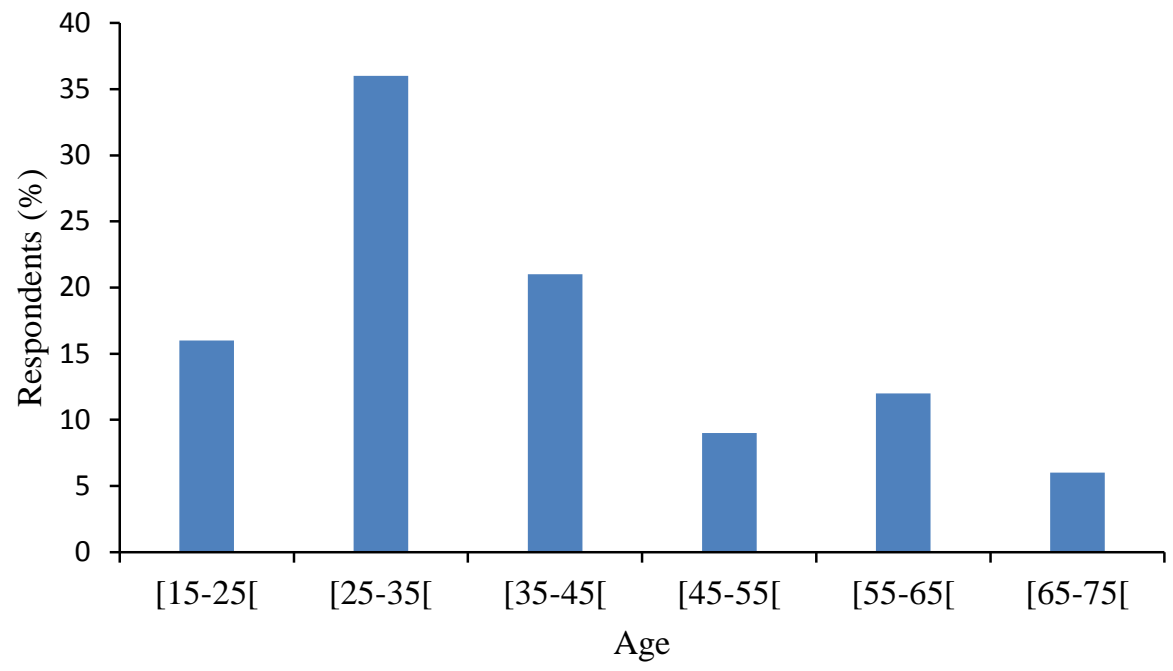

Figure 1: Distribution of the surveyed population by age group.

The number of the population surveyed on seed processing differed from one level of education to another. The uneducated people are the most represented $(41 \%)$, followed by those at the primary level $(36 \%)$. The least represented level is secondary (23\%) (Table 2). N'zebo et al. (2018) in Côte d'Ivoire on Tetrapleura tetraptera obtained similar results. These authors report that the uneducated people are the most represented (72.86\%). As the study area is a rural setting, this would be explain by the high rate of uneducated people. The production of this condiment is their main activity which generates a source of income.

Table 2: Education Level of the respondents.

\begin{tabular}{ll}
\hline Niveau d'instruction & Percentage \\
\hline Uneducated & 41 \\
Primary & 36 \\
Secondary & 23 \\
\hline
\end{tabular}




\subsection{Technology of Transformation of Seeds In "Dadawa"}

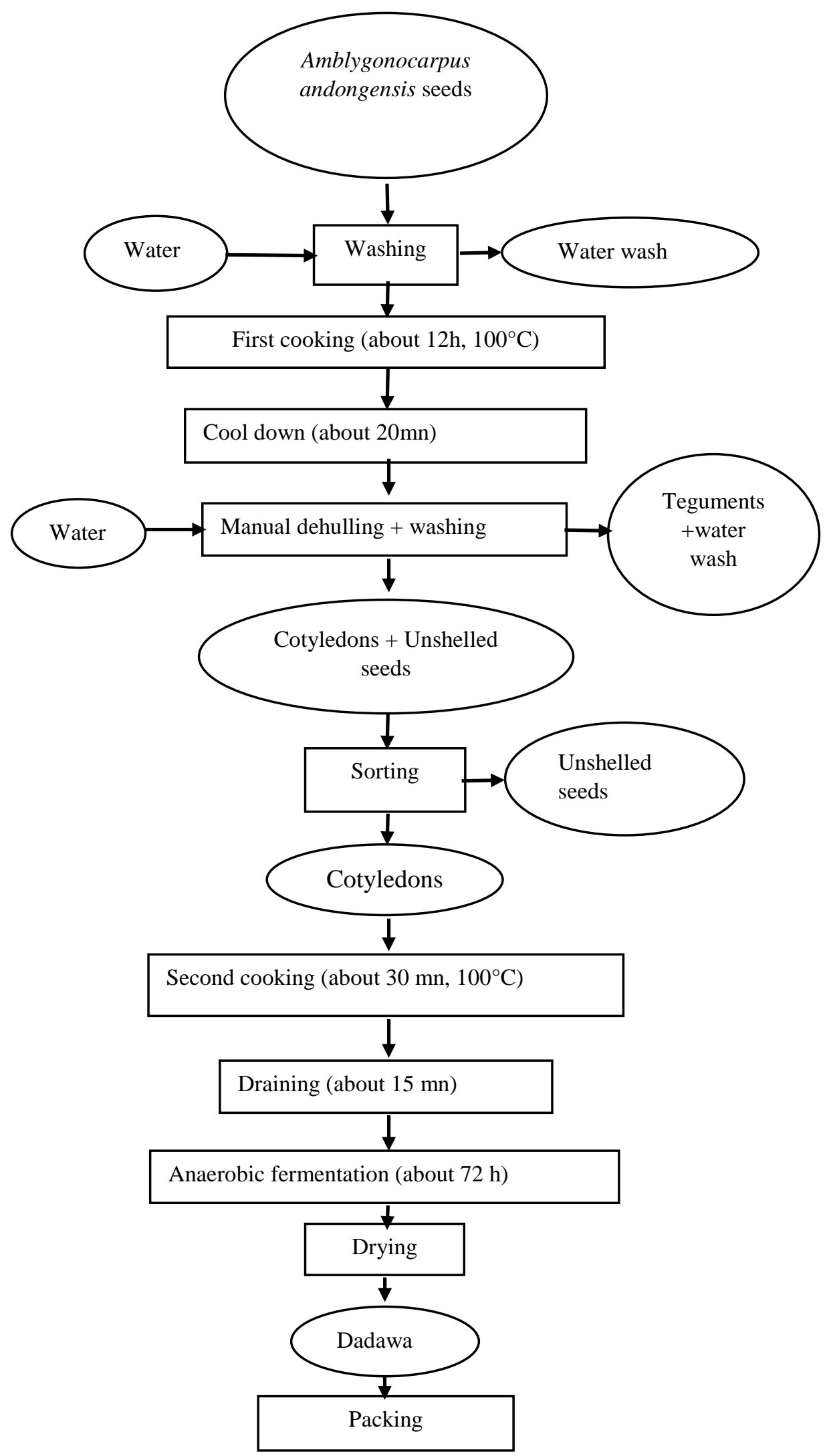

Figure 2: Traditional of making "Dadawa"from seeds of Amblygonocarpus andongensis 
To flavor their food, the rural population transforms the seeds of this plant and uses them as a spice. The process of making "dadawa" from the seeds of Amblygonocarpus andongensis is shown in figure 2 lacking more effort and time. It includes several operations. The seeds are washed to remove the impurities. After washing, the seeds are subjected to a first cooking. Cooking softens the shell of the seeds to facilitate peeling and keep only the cotyledons. This operation lasts approximately 12 hours. This operation lasts about 10 hours and prepares the seeds for shelling and fermentation (Azokpota et al., 2006). Then, the product is cooling about 15 minutes to facilitates the manual dehulling operation which separates the seed coats from the cotyledons. The shelling is carried out in a basin. This operation is tedious because the operator consumes energy and must simultaneously wash and rinse. According to the operators, this lasts operation make about 1 hour. Ahouansou (2012), in Benin on Parkia biglobosa obtained similar results. This author reports that afitin, iru and sonru are obtained using a very restrictive traditional process. Indeed, the shelling of Parkia biglobosa seeds, which is one of the main operations carried out during the production of the condiments, is very tedious and consumes energy and water (Koura et al., 2014). After rinsing, the operators proceed to sorting. The sorting operation removes unshelled seeds and any other defects that arise. The cotyledons thus obtained undergo a second firing which lasts approximately 30 minutes. These cotyledons are then drained using a colander for about 15 minutes, verify the fermentation is anaerobic and carried out using clean polyethylene bags in which the clean leaves of Annona senegalensis allow the cotyledons to be enveloped. These leaves help raise the temperature in the bags and give the fermented product a special taste. According to the processors. Fermentation causes physicochemical changes in the product which are provided by microorganisms. This operation lasts approximately 72 hours. These results are contrary to those obtained by Ndir et al. (2000) on Parkia biglobosa. These authors reported that, the development of Soumboula is long and lasts 96 to 120 hours. The fermented product is dried in the sun for approximately 48 days. The product obtained from the species Amblygonocarpus andongensis is more appreciated by the population of Nyambaka because its more pronounced taste than that obtained by the seeds of Parkia biglobosa. However, it is not well known despite its importance not only as a substitute for the maggi cube but the population surveyed uses it to treat some diseases such as stomach, ache and hypertension.

\section{CONCLUSION}

The present study analyzed the traditional production system of "dadawa" obtained from the seeds of Amblygonocarpus andongensis. This study reveal that the transformation of Amblygonocarpus andongensis to "dadawa" based on the seeds of this specie is similar to that obtained from the seed of Parkia biglobosa. The technological enhancement of this non-wood forest product requires in-depth studies on various themes for better understanding its nutritional constituents. Studies on the physicochemical characterization of the seeds of this species will be done to allow us to better understand its nutritional value. Work on the physicochemical, microbiological and organoleptic characterization of the fermented product derived from its seeds should be also carried out to allow its valorization

\section{REFERENCES}

Ahouansou, R. H. (2012). Contribution à la mise au point et à l'optimisation des équipements de transformation agroalimentaire au Bénin : Cas de la décortiqueuse de néré et de la presse d'afitin. Thèse de Doctorat Unique de l'Université d'Abomey-Calavi, pp $1-285$.

Alaoui, A., Laaribya, S., Gmira, N., \& Benchekroun, F. (2012). Le rôle de la femme dans le développement local et la préservation des ressources forestières : Cas de la commune de Sehoul au Maroc. Revue de la forêt méditerranéenne, 33(4), 369378

Azokpota, P., Hounhouigan, D.J., \& Nago, M.C. (2006). Microbiological and chemical changes during the fermentation of African locust bean (Parkia biglobosa) to produce afitin, iru, and sonru, three traditional condiments produced in Benin. Int. J. Food Microbiol., 107, 304-309.

Keay, R., Onochie, C., \& Stanfield D. (1964). Nigerian trees. Nigerian National Press Ltd. Apapa, Lagos. 2, 78-106.

Koura, K., Ibilola P., Ouidoh, G., Azokpota, P., Ganglo J.C., \& Hounhouigan, D. J. (2014). Caractérisation physique et composition chimique des graines de Parkia biglobosa (Jacq) en usage au Nord Benin. Journal. Appl.Biosci.75, 6239-6249

Lamy, G. M., Ibrahima, A., Ndjonka, D., \& Mapongmetsem P. M. (2018). Etude ethnobotanique des sous-variétés de Syzygium guineense (Will.) var. macrocarpum (Engl.) F. White dans les Hautes Savanes Guinéennes (Adamaoua, Cameroun). Int. J.Biol.Chem.Sci., 12(4), 1636-1649.

Letouzey Réne (1968). Etudes phytogeographiques du Cameroun. Encyclopédie Biologique. Edition Le chevalier. pp 1-511. 
Mapongmetsem, P. M. \& Laissou, M. (2010). Contribution à la domestication des fruitiers locaux : influence des substances de croissance sur l'enracinement des marcottes. Com. International Symposium, Indigenous fruit trees for dryland Africa: domestication for use in a changing environment. Allada, Benin. pp 1-12.

Mapongmetsem, P. M., Djeumene, P., Sonna, D., \& Ndoum J. F. (2008). Utilisation et commercialisation des produits forestiers non ligneux dans les savanes soudano- guinéennes du Cameroun. Com. Sympo. ANAFE, Malawi.14p.

Mapongmetsem, P. M., Kapehie, V., \& Tefempa, B. H. (2012). Diversity of local fruit tree and their contribution in sustaining the rural live lihood in the northem Cameroon. Ethiopian Journal of Environments al Studies and Management, 5(1):32-46.

Moupela, C., Vermeulen, C., Daïnou, K., \& Doucet, J. L. (2011). Le noisetier d'Afrique (Coula edulis Baill.). Un produit forestier non ligneux méconnu, 15(3), 485-495.

N'zebo, J. M., Dje, K. M., \& Ahi, A. P. (2018). État des connaissances et usages traditionnels des fruits de Tetrapleura tetraptera ((Schumach. \& Thonn.) Taub., 1891), plante spontanée aromatique alimentaire du sud-est de la Côte d'Ivoire. J. Anim \& Plant Sci., 38(1), 6190-6205.

Ndir, B., Lognay, G., Wathelet, B., Cornelius, C., Marlier, M., \& Thonart, P. (2000). Composition chimique du nététu, condiment alimentaire produit par fermentation des graines du caroubier africain Parkia biglobosa (Jacq.) Benth. Biotechnol. Agron. Soc. Environ., 4 (2), 101-105

Nwinyi, F. C., Ajoku, G. A., Aniagu, S. O., Kubmarawa, D., Enwerem, N., Dzarma, S., \& Inyang, U. S. (2006). Pharmacological justification for the ethnomedicinal use of Amblygonocarpus andongensis stem bark in pain relief. Afr. J. Biotechnol., 5(17), 1566-1571.

Ugwah, O. M., Ugwah-Oguejiofor, C. J., Abubakar, K., Okorie N. A., \& Njan A. A. (2014). Anti-diarrhoeal activities of aqueous stem bark extract of Amblygonocarpus andongensis (Welw.Ex Oliv.) Exell \& Torre. Niger. J. Pharma. Sci., 13(2), 01-11

Yonkeu Samuel (1983). Végétation des pâturages de l'Adamaoua (Cameroun) : écologie et potentialités pastorales. Thèse de Doctorat. Univ. Rennes I, France. pp 1-207.

*Corresponding author email: boursi.jeremie @yahoo.fr 